\title{
Fibrosis in tubularized skin flaps in rats, using silicon catheters with two different degrees of flexibility. Experimental model ${ }^{1}$
}

\author{
Fibrose em retalhos tubulizados de pele de ratos usando cateteres de diferentes \\ flexibilidades como molde. Modelo experimental
}

\author{
Antonio Henrique Rodrigues dos Passos', Fernando Costa ${ }^{\mathrm{II}}$, Lúcio Tedesco Marchese ${ }^{\mathrm{II}}$, Sergio Augusto Catanzaro \\ Guimarães $^{\text {III }}$, Wilson Aparecido Oreini ${ }^{\text {IV }}$ \\ ${ }^{\mathrm{I}}$ Master of Sci., Division of Pediatric Surgery of the College of Medicine of Marília (FAMEMA), São Paulo, Brazil. \\ ${ }^{\text {II }} \mathrm{PhD}$, Division of Pediatric Surgery, State University of Londrina (UEL), Paraná, Brazil. \\ ${ }^{\text {III }} \mathrm{PhD}$, Division of Odontology, University of Sagrado Coração (USC), Bauru - SP, Brazil. \\ IV Biologist, Laboratory of Molecular Biology, USC, Bauru - SP, Brazil.
}

\begin{abstract}
Purpose: Microscopically evaluate the intensity of fibrosis in tubularized skin flaps on the back of Wistar rats, using silicon molds with different degrees of flexibility. Methods: Twenty rats were submitted to three tubularized skin flaps on their backs. In two tubular flaps, we placed, as a mold, silicon catheters with different degrees of flexibility and removed them on the seventh day after the surgery. They were divided into two groups and euthanized, on the seventh and twenty-first days respectively after the surgery for the collection of the pieces, coloration with Masson tricromic, quantification of the area of each sample and comparison among the groups. Results: Fibrosis was less intense on the tubular flaps where a catheter was not used as a mold. No significant difference was verified among the pieces with the silicon catheters, but there was a tendency of less fibrosis on the tubules with the most flexible catheter. Conclusion: There was no significant difference among the two catheter types. Fibrosis was less intense in the flaps where the mold was not used.
\end{abstract}

Key words: Hypospadias. Surgical Flaps. Silicon. Fibrosis. Rats.

\section{RESUMO}

Objetivo: Avaliar microscopicamente a intensidade da fibrose em retalhos tubulares de pele do dorso de ratos Wistar em uso de moldes de silicone de diferentes flexibilidades. Métodos: Vinte animais foram submetidos à confecção de três retalhos tubulizados de pele na região dorsal. Em dois túbulos foram colocados, como molde, cateteres de silicone com flexibilidades diferentes e retirados no sétimo dia após a cirurgia. Foram divididos em dois grupos e sacrificados, respectivamente, no sétimo e vigésimo primeiro dia após a cirurgia para a coleta das peças, coloração pelo tricrômico de Masson, quantificação da área de cada amostra e comparação entre os grupos. Resultados: A fibrose foi menos intensa nos retalhos tubulares em que não se usou cateter como molde. Não se verificou diferença significativa entre os retalhos com os cateteres de silicone, mas sim, tendência de menos fibrose nos túbulos com cateter mais flexível. Conclusão: Não houve diferença significativa entre os dois tipos de cateter. A fibrose foi menos intensa nos retalhos onde não se utilizou molde.

Descritores: Hipospadia. Retalhos Cirúrgicos. Silicones. Fibrose. Ratos.

1. Research performed at State University of Londrina (UEL), Paraná, Brazil.

\section{Introduction}

The use of penile ventral skin for hypospadia repair has reappeared with the Snodgrass technique, which consists of a longitudinal incision on the urethral plate ${ }^{1-3}$. Hypospadia occurs approximately in one out of 300 liveborn boys ${ }^{4-6}$. From 1880 on, several techniques have been developed with the use of tubular skin flaps in the treatment of this malady. ${ }^{7}$

Complication rates in the postoperative period reach up to $10 \%$ and, among the most frequent, are the urethrocutaneous fistulas and the neo-urethra strictures. The latter, related to cicatrization and tissue fibrosis, require urethral dilations and even re-operations, which is very uncomfortable for the patient. Suture threads, the presence and the constitution of the catheters used as a mold have been related to complications. $^{3}$

This study, approved by the Bioethics Commission of the State University of Londrina, was performed in order to evaluate the intensity of fibrosis following the use of silicon molds, with different degrees of flexibilitiy, during the fibrotic process in tubularized skin flaps on the back of Wistar rats. 


\section{Methods}

The experimental study was performed from May to July 2006. Twenty syngeneic Wistar male rats with ages varying from 45 to 60 days were used.

Two types of silicon catheters with different degrees of flexibility were used as determined by resistance to the diametrical compression test according to the general guidelines of the DIN EM ISSO 604:2004 norm, performed by the Instituto de Pesquisas Tecnológicas do Estado de São Paulo (IPT).

Catheter " $A$ " had its diameter deformed in 0.8 millimeters, under compression imposed with a medium load of 1.14 Newton (N). Catheter "B" had the same deformation with a medium load of $2.02 \mathrm{~N}$.

The surgical procedure consisted of making three tubular flaps on the dorsal area of the rat. Each flap had two $10 \mathrm{~mm}$ long parallel incisions, transversal to the spine of the animal, distant $8 \mathrm{~mm}$ from each other, measured with a paquimeter. Then, a rectangle was formed with the incisioned transversal sides $(10 \mathrm{~mm})$ and the longitudinal sides $(8 \mathrm{~mm})$ left intact (Figure 1). Next, as described on the TIP (tubularized incised plate) technique, the internal margins were inverted and sutured in a continuous way in a unique plan of the layer with a \# 6.0 PDS ${ }^{\circledR}$ (polidioxanone) thread, forming a tube to be covered by suturing the external edges of the incision with separate stitches with \# 5.0 mononylon. The caudal tubular flap was left without a catheter (SS). In the cranial flap, the suture was performed on the silicon "A" catheter (SA) with $2 \mathrm{~mm}$ of external diameter and $6.3 \mathrm{~mm}$ of perimeter. In the flap located in the center, we used, as a mold, the silicon " $\mathrm{B}$ " catheter $(\mathrm{SB})$ with the same measures of the A mold.

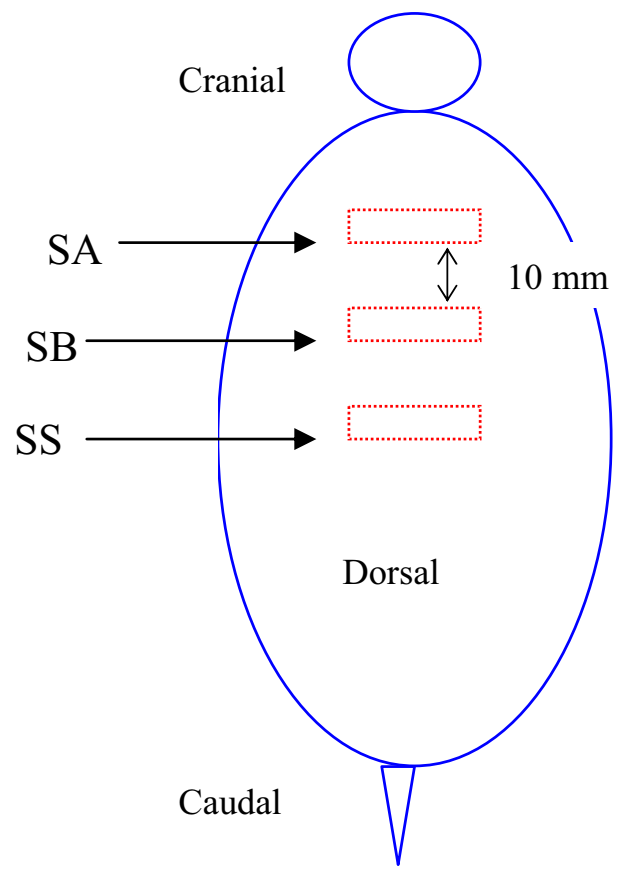

FIGURA 1 - Experimental model. Three tubular flaps (red rectangle) on the dorsal area of the rat (blue)

All the procedures were performed by the same surgeon.
The animals were divided into two groups for the collection of the flaps and histopathological analysis. Ten animals were euthanized on the seventh day after the surgery (Group I). The other ten animals (Group II) were anesthetized on the seventh day after the surgery for the removal of the catheters and submitted to euthanasia on the $21^{\text {st }}$ day after the surgery.

The histopathological sections were colored with Masson tricromic and positioned in an optical microscope with a camera connected to it. Twenty times magnified images were captured and transferred to the image analysis program (Image Pro 4.5). In each histological section we determined 3 regular square samples in the area juxtaposed to the lumen of the tubular flap, containing dermis and epidermis. The structures colored by Masson tricromic in green/blue were intensified and quantified in percentage in the area of each sample. Thus, the average of each microscope slide from the three samples was obtained. These data were compared at a significance level of $5 \%(\mathrm{p}=0.05)$. We used the Excel ${ }^{\circledR}$ spreadsheet, the Bioestat ${ }^{\circledR}$ software and the ANOVA and Bonferroni statistical tests to analyze the data gathered.

\section{Results}

In Group I, there was a significant difference on the coloring in situations A (more flexible catheter) where the average was $72.37 \%$ and S (without catheter), with average of $65.73 \%$. The same situation happened in situations B (less flexible catheter), with $75.17 \%$, and S. There was no significant difference between situations A and B. The same analyses occurred in Group II where the averages were $78.63 \%$ in situation A, $81.29 \%$ in situation B and $75.32 \%$ in the situation where the catheter was not used as a mold. In the three situations, there was a significant difference between groups I and II (Table 1).

TABLE 1 - Mean (\%), standard deviation and statistic result of image caption on situations SA, SB and SS, on Groups I and II

\begin{tabular}{ccccc}
\hline Group & SA & SB & SS & p-value \\
\hline I & $72,37 \pm 5,96$ & $75,17 \pm 6,75$ & $65,73 \pm 6,21$ & $0,0077^{*}$ \\
II & $78,63 \pm 4,89$ & $81,29 \pm 4,44$ & $75,32 \pm 4,79$ & $0,0287^{*}$ \\
\hline p-value & 0.0096 & 0.0138 & 0.0005 &
\end{tabular}

* Comparison between SS and situations with catheter (SA and SB).

Assembling Groups I and II, an average of $75.5 \%$ in the color reception in situation $\mathrm{A}, 78.23 \%$ in situation $\mathrm{B}$ and $70.53 \%$ in situation $\mathrm{S}$ was obtained. There was a significant difference between situation $\mathrm{S}$ and the two situations where the silicon catheter was used as a mold. There was no significant difference between situations A and B (Table 2).

TABLE 2 - Mean (\%), standard deviation and statistic result of image caption on situations SA, SB and SS

\begin{tabular}{cccc}
\hline AS & SB & SS & p-value \\
\hline $75,50 \pm 6,21$ & $78,23 \pm 6,39$ & $70,53 \pm 7,30$ & $0,0024^{*}$ \\
\hline *Comparison between SS and situations with catheter (SA and SB).
\end{tabular}


In situation $\mathrm{S}, 75 \%$ of the values of the selected color receptions, which corresponded to fibrosis, were smaller than $75.09 \%$ of the area of the samples. Only $25 \%$ were considered larger than this reception value. In situations SA and SB, this same percentile was $78.92 \%$ and $82.84 \%$ respectively (Table 3 and Figure 2).

TABLE 3 - Distribution, in percentiles, of values on image caption areas on situations SA, SB and SS

\begin{tabular}{c|ccc}
\hline Percentile & SA (\%) & SB (\%) & SS (\%) \\
\hline Minimum value & 62,33 & 62,43 & 58,30 \\
25 & 73,18 & 74,83 & 65,75 \\
50 & 75,42 & 80,78 & 71,18 \\
75 & 78,92 & 82,84 & 75,09 \\
Maximum value & 85,13 & 86,90 & 85,00 \\
\hline
\end{tabular}

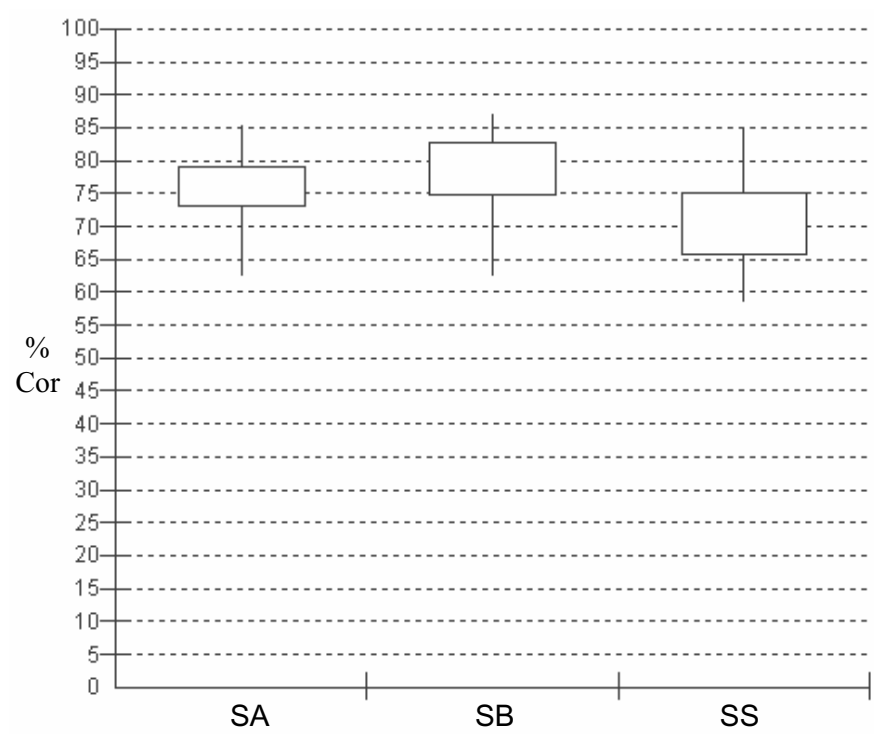

FIGURE 2 - Distribution of values on areas of image caption on situations SA, SB and SS

\section{Discussion}

Urethral strictures, after hypospadia repair, are undesirable complications for the patient, for the family and for the surgeon ${ }^{9}$. Its treatment consists of the uncomfortable urethral dilation and, even, a new surgery.

DiSandro and Palmer ${ }^{9}$ reported urethral stenosis in $13.3 \%$ of 117 studied patients and related this complication to the absorption time of the thread used in the sutures. The authors cited Secrest et al. that reported 34\% of stenosis in 190 operated patients. The vascularization of the adjacent skin was considered one of the contributing factors ${ }^{9}$. Authors such as Mathieu, MAGPI, and others used many different techniques.

Urethral stenosis generally happens in the proximal anastomosis due to the caliber difference between the neo-urethra and the original urethra, to the angulation of the longitudinal urethral axis, and to inadequate skin and pedicle flap vascularization $^{4}$. Described by Snodgrass ${ }^{2}$, the technique of tubularization of the adjacent skin with a longitudinal incision of the urethral plate, called TIP (tubularized incised plate), has been thoroughly used for hypospadia repair due to its feasibil- ity, to the smallest occurrence of complications and a satisfactory esthetic and functional aspect ${ }^{1}$. The cicatrization of the urethral plate incision favors re-epithelization of the adjacent vascularized tissue ${ }^{10}$. According to Anwar-ul-Haq et al. ${ }^{1}$, this reepithelization justifies the use of the urethral catheter as a mold for a minimum of 5 days.

There are controversies regarding the risks and benefits of using catheters to mold the neo-urethra and to promote urinary diversion. Buson et al. ${ }^{11}$ reported a smaller incidence of fistulas and stenoses with the use of urethral catheters ${ }^{11-13}$. However, Hakim et al. ${ }^{14}$ stated that the decrease in the incidence of fistulas is due to the preservation of the vascularization of the flaps during surgery ${ }^{14}$. Other papers point out that the use of a catheter for bladder drainage decreases the patient's mobility, increases hospital stay, causes pressure on the neo urethra, thus leading to ischemia and, as a foreign body, increasing the risk of infection ${ }^{15-17}$.

In an attempt to simulate hypospadia repair with skin tubularization, an experimental model was idealized with rats. Those animals were chosen because they are easy to handle and because they were available in the Animal Room of our institution. However, this model invalidated the use of the catheter in different derivational ways: urethral stent and indwelling catheter, and also because it is performed on the animal back skin where its fur is different from the one on the genital area.

In this study, we observed less fibrosis in the flaps with a more flexible catheter in comparison to the flaps with a less flexible catheter, with no statistical significance. The graph makes it evident that on the flaps where the mold was inserted with a harder silicon catheter there was a higher percentage of fibrosis, followed by situation A and by the situation where a mold was not used. We can also say that in situation $\mathrm{S}$, there was a larger dispersion of the data, because the 25 percentile is higher than the 75 percentile. Perhaps it happened due to the higher capacity of complacence to the adjacent tissue edema. The less flexible catheter had probably a smaller accommodation to the circumferential pressure made by the edema and, therefore, due to the action/reaction principle, there was less vascularization in the tissue and, consequently, more fibrosis, similar to what happened in the model proposed by Lopes et al. ${ }^{10}$ This explanation is confirmed when comparing the group with no catheter with those in which the mold was used. In the absence of the catheter, there was significantly less fibrosis.

Comparing Groups I and II, it was observed that time interferes in the fibrotic process, once there was a significant difference in the three situations.

Chiquetti et al. ${ }^{18}$ stated that the use of image analysis software reduces the factors that generally induce to misinterpretation when analyzed by the pathologist, directly in the common optical microscope. It should be considered that, in this study, the image analysis program was used to quantify the selected structure based on the amount of color in comparison with the other structures on the same histological section. In an attempt to be more objective, three regular square samples of the area juxtaposed to the lumen of the tubular flap were collected, and the average for each histological section was calculated. 
Although there was no significant difference, the results suggested that the catheter made of more flexible silicon caused less fibrosis and, thus a lower possibility of stenosis. Perhaps, it would have been evident if we had performed the experiment with a less flexible catheter than the one used (catheter B), that is, we should have compared catheters with higher resistance difference to the diametrical compression. It is also necessary to consider that it is an experimental model in animals, free from the presence of the urinary flow. For some surgeons in favor of the catheter, its use is indicated to mold the neo-urethra, to stabilize the suture line, to drain the urine during cicatrization and to avoid the miccional discomfort in the first days after the surgery ${ }^{1,8,11}$.

We should also be attentive to the caliber of the catheter lumen to be used as a mold of the constructed neo-urethra. In the material used in this study, the catheter made of less flexible silicon had a smaller internal diameter, which can make the urinary flow difficult, if used for hypospadia correction. When using more flexible catheters, we must observe the possibility of crinkles in the intra-vesical part and/or distally to the urethral meatus, obstructing the urinary flow.

\section{Conclusion}

There was no significant difference among the two types of catheter. Fibrosis was less intense in the pieces where the mold was not used.

\section{References}

1. Anwar-ul-Haq, Akhter N, Nilofer, Samiullah, Javeria. Comparative study of Mathieu and Snodgrass repair for anterior hypospadias. J Ayub Med Coll Abbottabad. 2006;18(2):50-2.

2. Snodgrass W. Tubularized, incised plate urethroplasty for distal hypospadias. J Urol. 1994;151(2):464-5.

3. O’Connor KM, Kiely EA. Lessons learned using Snodgrass hypospadias repair. Ir J Med Sci. 2006;175(1):37-9.

4. Duckett JW, Baskin LS. Hypospadias. In: O’Neill JA, Rowe MI, Grosfeld JL, Fonkalsrud EW, Coran AG. Pediatric surgery. 5ed. Philadelphia: Mosby; 1998. p.1761-81.

5. Macedo Jr M, Srougi M. Hipospádias. Rev Assoc Med Brasil. 1998;44(2):141-5.

6. Dodson JL, Baird AD,Baker LA, Docimo SG, Mathews RI.
Outcomes of delayed hypospadias repair: implications for decision making. J Urol. 2007;178(1):278-81.

7. Duplay S. De hipospadias perinio scrotal et de son traitement chirurgical. Archs Gen Med. 1880; 23:513 (Apud Velhote MCP. Hipospadias. In: Maksoud JG. Cirurgia Pediátrica. $2^{\mathrm{a}}$ ed. Rio de Janeiro: Revinter, 2003. P.1144-62.

8. Passos AHR, Costa F, Marchese LT. Estudo comparativo de retalhos tubulares de pele de ratos com dois tipos de cateter como molde. Rev Col Bras Cir. 2006;33(1):39-44.

9. DiSandro M, Palmer JM. Stricture incidence related to suture material in hypospadias surgery. J Pediatr Surg. 1996;31(7):881-4.

10. Lopes JF, Schned A, Ellsworth PI, Cedron M. Histological analysis of urethral healing after tabularized incised plate urethroplasty. J Urol. 2001;166(3):1014-7.

11. Buson H, Smiley D, Reinberg Y, Gonzalez R. Distal hypospadias repair without stents: is it better? J Urol. 1994;151:105960 .

12. Mitchell M, Kulb TB. Hypospadias repair without a bladder drainage catheter. Urology. 1986;135:321-3.

13. Palmer LS, Palmer JS, Franco I, Friedman SC, Kolligian ME, Gill B, Levitt SB. The "long snodgrass": applying the tubularized incised plate urethroplasty to penoscrotal hypospadias in 1-stage or 2-stage repairs. J Urol. 2002;168:1748-50.

14. Hakim S, Merguerian PA, Rabinowitz R, Shortliffe LD, McKenna PH. Outcome analysis of the modified Mathieu hypospadias repair: comparison of stented and unstented repairs. Urology. 1996;156:836-8.

15. Rabinowitz R. Outpatient catheterless modified Mathieu hypospadias repair. Urology. 1987;138:1074-6.

16. Laclair MD, Camby C, Battisti S, Renaud G, Plattner V, Heloury Y. Unstented tubularized incised plate urethroplasty combined with foreskin reconstruction for distal hypospadias. Eur Urol. 2004;46:526-30.

17. Samuel M, Capps S, Worthy A. Distal hypospadias: which repair? BJU Int. 2002;90(1):88-91.

18. Chiquetti Jr A, Rodrigues MAF, Delfino VDA. An experimental model for the study of drug effects on cutaneous healing. Acta Cir Bras. 2007;22(4):316-20.

\section{Acknowledgments}

Molecular Biology Laboratory of Sagrado Coração University, Baurú, São Paulo,Brazil.

\section{Correspondence:}

Antonio Henrique Rodrigues dos Passos

Conflict of interest: none

Av. Santo Antonio, 4561

17507-050 Marília - SP Brazil

Phone: (55 14)3422-3185

Received: November 23, 2007

ahrpassos@uol.com.br

\section{How to cite this article}

Passos AHR, Costa F, Marchese LT, Guimarães SAC, Oreini WA. Fibrosis in tubulized skin flaps in rats using silicon catheters of two different flexibility: experimental model. Acta Cir Bras. [serial on the Internet] 2008 May-June;23(3). Available from URL: http://www.scielo.br/acb

*Color figure available from $\underline{w w w . s c i e l o . b r / a c b}$ 